\section{A NEW PATTERN OF SCISSORS FOR PERINEAL REPAIR.}

MessRs. Down Brothers, of St. Thomas's-street, Borough, have constructed for me a pair of scissors which are much better for flap-splitting operations than anything I have seen before. They are slim but firm in the blades, the points are very carefully made, and the blades slope gradually to the hilt, so that the flaps can be made with one cut each, and therefore will have perfectly true surfaces-a matter of much importance and I fear, not sufficiently attended to. The joint is a beautiful French contrivance which I first saw on a pair of catch-forceps, and have adapted it to scissors, where it has the important advantage of keeping the cutting edges of the two blades in accurate adaptation. It also enables the blades to be unshipped instantly, and is

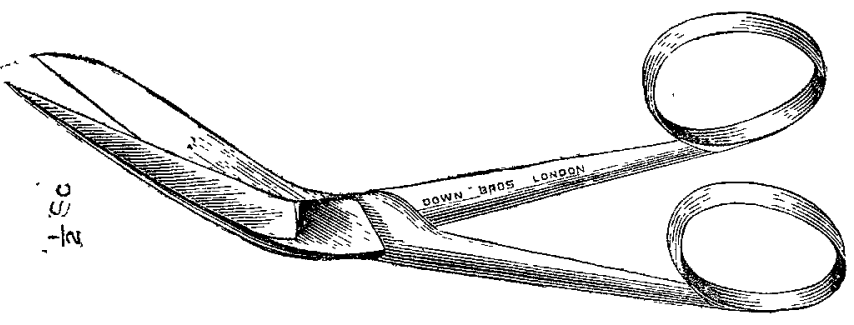

therefore an advantage for aseptic purposes. From the number of cases coming to me of failure of what is said to have been "Tait's" operation I fear my original instructions are not being carried out, for I have altered the operation in no particular and I have no failures to record. My rules are: cut cleanly and deeply on the white cicatricial lines which indicate the healing of the original tear; insert the stitches deeply within the skin margin and miss about half an inch at the bottom of the wound. Use salmon gut sutures and tie tightly. Close the skin wound, if needful, by a few superficial sutures. Keep the vagina clean by washing out with soap and water night and morning, and keep the rectum empty.

Birmingham.

Lawson TaIt, F.R.C.S. Eng. and Edin.

\section{NEW PATELLA SPLINT.}

THIS splint I have used with complete success in the treatment of fracture of the patella, and in my opinion it is the best appliance for that injury. It consists of a wooden trough with foot-board, in which I fix the limb. Along the upper border of the patella should be placed a padded cord, with lengths extending down both sides of the leg to a pin or screw fixed in the sides of the troughs at about five or six inches distant from the centre of the fracture. Upon tightening this cord apposition of the upper with the lower

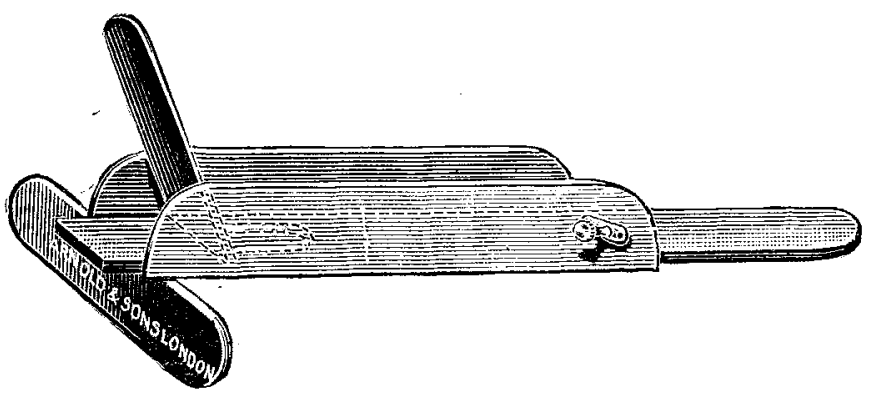

portion of the patella is perfected. No constriction of adjacent tissue occurs to endanger punctual ossification and union. By making the two pins (to which the cord is frstened) as rotating screws tension is easily adjusted for exact apposition of the displaced fragment. The usual $V$ posing of the patient is unnecessary; thus another hindrance to the freedom of circulation is dispensed with-a serious consideration in treating these cases.

Fred. Dalton, L.R.C.P. Lond., M.R.C.S. Eng.

Rottingdean, Brighton.

\section{COMBINED TONGUE DEPRESSOR AND INSUFFLATOR.}

A COMBINED tongue depressor and insufflator, invented by Mr. W. Thomas, of Bridgend, Glamorganshire, has been sent to us by Messrs. Woolley, Sons, and Co., Limited, of Manchester. The instrument is in one piece, and therefore easily rendered aseptic by immersion in boiling water, and is provided with a glass screen, which, while allowing a good view of the fauces to be obtained, prevents the operator being infected by the child coughing. 'The instrument will be chiefly of use for insufflating the throats of children, as, for instance, with sulphur in diphtheria, as inspection and insufflation can be carried out simultaneously. The instru. ment is strong and well finished, and can be obtained, complete, for $8 s .6 d$.

\section{SPUTUM BOX AND STAINS.}

Mr. Fearnder of Harrogate has lately introduced a boz containing all the requisites for examining sputum and excreta for the tubercle bacilli. The box contains carbolfuchsine and acid methylene blue in very convenient drop bottles, slides, cover glasses, cedar oil for mounting, spirit lamp, vessels for water, filter papers, scissors, forceps, \&c. The box is accompanied by directions by Mr. Fearnley for the use of the stains which are so admirably clear that any. one without previous training can make reliable preparations if he carries them out carefully, and the whole process need not take more than ten minutes. The stains supplied are of excellent quality. The sputum box will be a great boon to. the busy country practitioner, who can easily make reliable preparations for bimself at once, and will not have to wait until he has obtained a report from some distant authority. The box can be obtained from Mr. Freshfield Reynolds, pharmacentical chemist, Harrogate, price 12s. $6 d$.

\section{THE PROPOSED CENTRAL HOSPITAL BOARD.}

THE following is the text of the petition to be presented to His Royal Highness the Prince of Wales concerning the formation of a Central Hospital Board :-

TO HIS ROYAL HIGHNESS THE PRINCE OF WALES, K.G., \&. We, the undersigned members of the Medical Profession in London, and others interested in the welfare of Metropolitan medical charities, humbly venture to submit to Your Koyal Highness the following short statement, in the hope that Your Royal Highness may be willing to accede to our petition.

In accordance with a communication addressed by Your Royal Highness to the Public, the Prince of Wales's Hospital Fund for London has been established in honour of the Diamond Jubilee of our Most Gracious Majesty the Queen.

To this Fund a very large sum has already been contributed, both in commemoration of Her Majesty's reign, and in the hope that the hospitals of London may be relieved from the heavy financial pressure from which many of them are suffering.

The establisbment and maintenance of so large a Fund under Your Royal Highness's auspices will affect the condition of the hospitals of London for many years to come.

For the distribution of so important a public gift, we venture, in the interests of the poor, the Public, and the hospitals themselves, to urge the formation, at an early date, of a Central Hospital Board, including, lay and medical representatives of the medical charities of the Metropolis.

This proposal has already received the approval of a large number of the members of medical profession, and of many others interested in the welfare of

Established with your Royal Highness's sanction, such a Board would do much to promote consultation and coöperation amongst those who are attached to, or engaged in the management of, London hospitals. are attached to,

Conspensaries. pitals to deal with some of the acknowledged difficulties of their work, as, for instance, the regulation of the out-patient departments.

The Central Board would also be a guarantee to the contributors that the fund would aid the hospitals in the most thorough and satisfactory manner ; by furthering the development of medical charity in such a way as to meet the wants of the growing population of the metropolis ; and by preventing those evils of pauperism and dependence which medical relief cannot but produce, if it be not administered with care and discretion and in accordance with sound principles of charity.

All this we would submit to Your Royal Highness, and would at the same time beg that, in view of the great importance of the subject, Your Royal Highness will receive a deputation of leading members of the medical profession and others interested in medical charities, in order that they may explain personally their reasons for asking Your Royal Highness to consider the proposal that we have ventured to make.

And your Petitioners will ever pray. 